ARTICLE

https://doi.org/10.1038/s41467-019-11544-8

\title{
Anode interfacial layer formation via reductive ethyl detaching of organic iodide in lithium-oxygen batteries
}

Xiao-Ping Zhang ${ }^{1,2}$, Yi-Yang Sun ${ }^{1}$, Zhuang Sun ${ }^{1}$, Chu-Shu Yang ${ }^{1,2} \&$ Tao Zhang $\mathbb{D}^{1,2}$

As soluble catalysts, redox mediators can reduce the high charging overpotential of lithiumoxygen batteries by providing sufficient liquid-solid interface for lithium peroxide decomposition. However, the redox mediators usually introduce undesirable reactions. In particular, the so-called "shuttle effect" leads to the loss of both the redox mediators and electrical energy efficiency. In this study, an organic compound, triethylsulfonium iodide, is found to act bifunctionally as both a redox mediator and a solid electrolyte interphase-forming agent for lithium-oxygen batteries. During charging, the organic iodide exhibits comparable lithium peroxide-oxidizing capability with inorganic iodides. Meanwhile, it in situ generates an interfacial layer on lithium anode via reductive ethyl detaching and the subsequent oxidation. This layer prevents the lithium anode from reacting with the redox mediators and allows efficient lithium-ion transfer leading to dendrite-free lithium anode. Significantly improved cycling performance has been achieved by the bifunctional organic iodide redox mediator.

\footnotetext{
${ }^{1}$ State Key Lab of High Performance Ceramics and Superfine microstructure, Shanghai Institute of Ceramics, Chinese Academy of Sciences, 1295 Dingxi Road, 200050 Shanghai, People's Republic of China. ${ }^{2}$ Center of Materials Science and Optoelectronics Engineering, University of Chinese Academy of Sciences, 100049 Beijing, People's Republic of China. Correspondence and requests for materials should be addressed to T.Z. (email: taozhang@mail.sic.ac.cn)
} 
ithium metal with high theoretical specific capacity (3860 $\mathrm{mAh} \mathrm{g}^{-1}$ ) and the lowest negative electrochemical potential $(-3.04 \mathrm{~V}$ vs. SHE) has been extensively studied for nextgeneration lithium metal batteries including $\mathrm{Li}-\mathrm{S}, \mathrm{Li}-\mathrm{O}_{2}$, and solidstate Li-metal batteries. A lithium metal anode faces two major challenges: the formation of a stable solid electrolyte interphase (SEI) and the ability to electrodeposit lithium non-dendritically. From the electrochemical point of view, the lithium metal SEI layer must permit fast Li-ion transport while simultaneously block electron transfer through the SEI layer. This is of paramount importance for establishing a completely reversible $\mathrm{Li}^{+} / \mathrm{Li}$ charge transfer process. The SEI components determine the rechargeable ability of lithium metal anode, as reflected by Coulombic efficiency, cycling performance, as well as dendrite growth. Intensive research has focused on modifying lithium metal anode by an artificial scaffold to enhance the stability of the spontaneously formed SEI layer ${ }^{1-6}$. Such approaches, called interfacial engineering, are typically realized by modifying the salts in electrolytes ${ }^{1,4}$, inorganic $\mathrm{Al}_{2} \mathrm{O}_{3}$ or $\mathrm{AlF}_{3}$ framework ${ }^{2,5}$, double polymer network ${ }^{3}$, and hard solid-state ceramics $^{6}$. These attempts have successfully advanced the lithium metal anode technique. Meanwhile, significant interest has been spurred in studying the formation and degradation mechanism of SEI components related to the complexity of electrolytes with different solvents, solutes, and shuttled active species. For instance, (1) how to rationally control the organic components in a common organic-inorganic hybrid SEI layer; (2) how the SEI layer evolves under the interaction with shuttled oxygen intermediates, polysulphides or redox mediators (RMs). These questions still remain to be resolved.

Oxygen species, including $\mathrm{O}_{2}$ radical and $\mathrm{LiO}_{2}$ intermediates are inevitable when we consider the SEI-related issues in $\mathrm{Li}-\mathrm{O}_{2}$ batteries $^{7-9}$. At the same time, reducing large overpotential upon charging is a key issue in the further development of $\mathrm{Li}-\mathrm{O}_{2}$ batteries ${ }^{10,11}$. Recently, dissolved RMs were proposed as molecular shuttles to promote the charge transfer between $\mathrm{Li}_{2} \mathrm{O}_{2}$ surface and air cathode that resulted in accurate charging at moderate voltages $^{12}$. Up to now, researchers have studied several $\mathrm{RMs}$ in $\mathrm{Li}-\mathrm{O}_{2}$ cells. Chen et al. combined a solution of tetrathiafulvalene (TTF/ $\mathrm{TTF}^{+}$) in DMSO with a nanoporous gold cathode, which could reduce the charging overpotential ${ }^{12}$. Lim et al. introduced lithium iodide $\left(\mathrm{I}_{3}-/ \mathrm{I}_{2}\right)$ redox couple in tetra(ethylene)glycol dimethyl (TEGDME), which exhibited stable cycle performance ${ }^{13}$. Other RMs, such as iron phthalocyanine $(\mathrm{FePc})^{14}$, 2,2,6,6-tetramethylpiperidinyloxy(TEMPO) ${ }^{10}$, tris[4-(diethylaminophenyl]amine $(\text { TDPA })^{15}$, cobalt bis(terpyridine $)-\left(\operatorname{Co}(\text { Terp })_{2}\right)^{16}$, and $\mathrm{N}$-methyl-phenothiazine (MPT) ${ }^{17}$ were also suggested. The incorporation of RMs efficiently reduces charge polarization. However, side reactions accompanied by the RMs lead to the degradation of the catalytic activity, which results in gradually increased charging overpotential after a certain number of cycles ${ }^{18}$.

The increased charging overpotential has been considered to be a shuttle effect related to the diffusion of soluble RMs during the charging process ${ }^{19}$. Oxidized RMs could diffuse through the separator and be reduced at the Li metal anode, leading to the deactivation of the RMs and the decline of electrical energy efficiency during charging process ${ }^{20}$. To avoid the shuttle effect, solid-state electrolytes and modified separators were suggested to protect the $\mathrm{Li}$ anode from the side reactions to achieve high cycling performance ${ }^{18,21-23}$. However, these ex situ protective layers suffer from interface separation after repeated cycling. In our previous study, we proposed an in-situ method by introducing indium triiodide $\left(\mathrm{InI}_{3}\right)$ to suppress the shuttle effect. Pre-depositing indium layer on the Li surface efficiently prevents the RMs from being reduced at the $\mathrm{Li}$ anode $^{24}$. Meanwhile, we noticed that this inorganic metallic protective layer is an electronic conductor. An indium-lithium
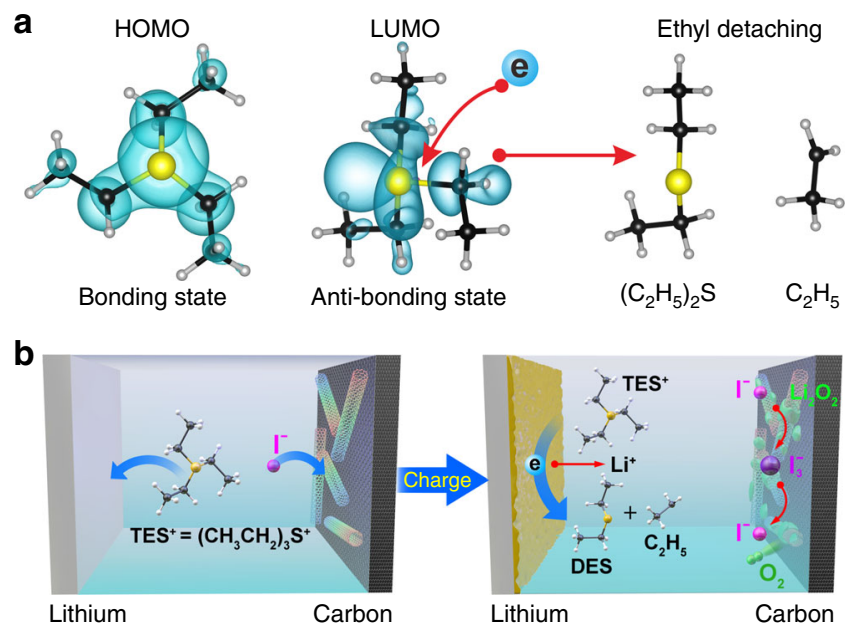

Fig. 1 In-situ formation process of SEl-like layer on Li anode. a Calculated $\mathrm{HOMO}$ and LUMO orbitals of a TES+ cation. $\mathbf{b}$ Schematic illustration of the in-situ formation process of SEl-like layer on Li anode during charging

alloying process and minor lithium loss still happen at every charging process.

Here we propose organic iodides as bifunctional $\mathrm{RMs}$ for $\mathrm{Li}-\mathrm{O}_{2}$ batteries. These organic iodides not only reduce the charging overpotential, but also represent a novel strategy to protect the $\mathrm{Li}$ anode from the $\mathrm{I}_{3}{ }^{-}$attack. During charging, the organic cation in the TEGDME electrolyte deposits on the surface of the Li anode, in situ forming a thin organic film, serving as a SEI-like layer. Different from the previous metallic indium layer, this organic layer is not only a Li-ion conductor, but also an electron insulator. Meanwhile, the SEI-like layer contains organic compounds, which exhibits good flexibility and strong affinity to the Li metal surface. In this case, it is possible that the organic iodide prevents the lithium anode from being attacked by the soluble $\mathrm{I}_{3}^{-}$, while retaining its $\mathrm{RM}$ function. There is a great variety of organic iodide compounds, such as triethylsulfonium iodide (Supplementary Fig. 1), choline iodide, tetramethylammonium iodide, trimethylsulfoxonium iodide, et al. In the Supporting Information (SI), we provide a partial list of organic iodides in Supplementary Fig. 2.

In this work, we find that triethylsulfonium iodide $\left(\mathrm{C}_{6} \mathrm{H}_{15} \mathrm{SI}\right.$, TESI) exhibits bifunctional behavior, i.e., acting as both an efficient RM and in situ SEI-like layer forming agent on lithium anode through reductive ethyl detaching and subsequent oxidation. The SEI-like layer contains organic and inorganic components, which efficiently prevent the attack of soluble $\mathrm{I}_{3}{ }^{-}$and transport Li-ions. When the TESI additive is added, the battery yields stable cycling performance and high energy efficiency.

\section{Results}

In-situ formation of SEI-like layer on $\mathbf{~ i i}$ anode. Choosing TESI in this work was based on the following considerations: (1) $\mathrm{InI}_{3}$ has been demonstrated to be an effective bifunctional RM except the unwanted alloying of In and Li metal; (2) In the oxidation environment, alkyl group is easily oxidized into lithium carboxylate, which is a well-known component in $\mathrm{SEI}^{25}$. A thin film on $\mathrm{Li}$ anode based on lithium carboxylate serves as an insulating SEIlike layer. Our density functional theory calculation suggests that the triethylsulfonium cation $\left(\mathrm{TES}^{+}\right)$could provide the required ethyl group in a reductive environment. Figure 1a shows the calculated HOMO and LUMO orbitals of a TES ${ }^{+}$cation. While HOMO is a symmetric bonding orbital, LUMO exhibits a clear nodal surface between one ethyl group and the remaining part of the cation. When acquiring an electron from the $\mathrm{Li}$ anode, the 

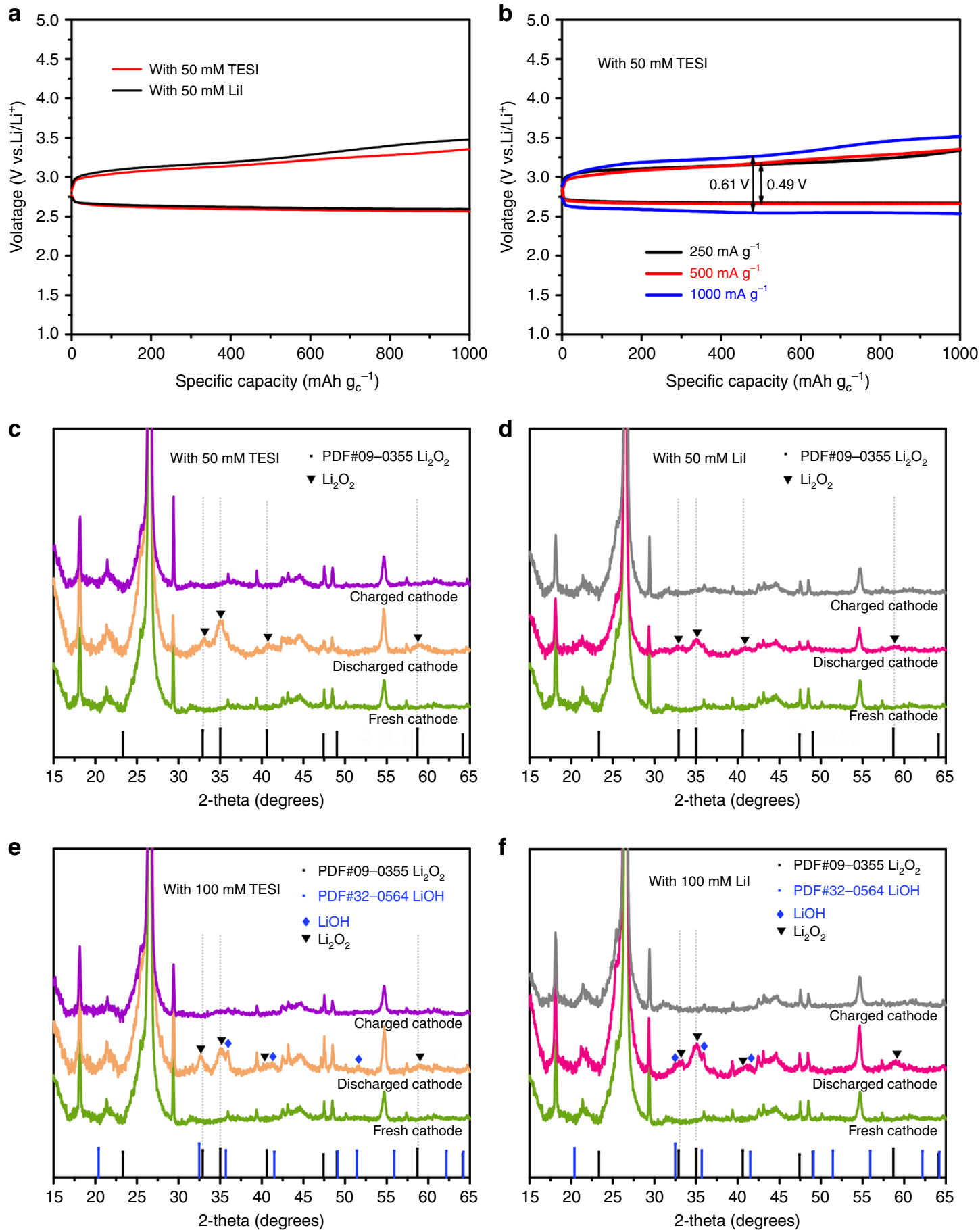

Fig. 2 Electrochemical performance and XRD patterns of the $\mathrm{Li}_{-} \mathrm{O}_{2}$ cells with TESI or Lil additives. a Galvanostatic discharge/charge profile at $500 \mathrm{~mA} \mathrm{~g}{ }^{-1}$ with $50 \mathrm{mM}$ TESI or $50 \mathrm{mM}$ Lil additives at a limited specific capacity of $1000 \mathrm{mAh} \mathrm{g}^{-1}$. b With $50 \mathrm{mM}$ TESI additive for the first cycle, current density: 250,500 and $1000 \mathrm{~mA} \mathrm{~g}^{-1}$. XRD patterns of the cathode at the end of discharge and the cathode at the end of charge with (c) $50 \mathrm{mM}$ TESI additive, (d) with $50 \mathrm{mM}$ Lil additive, (e) with $100 \mathrm{mM}$ TESI additive, (f) with $100 \mathrm{mM}$ Lil additive

occupation of the LUMO will promote the detaching of that ethyl group from TES $^{+}$forming diethyl sulfide $\mathrm{C}_{4} \mathrm{H}_{10} \mathrm{~S}$ (DES) and an ethyl radical. The reductive ethyl detaching reaction is:

$$
\mathrm{Li}(\text { metal })+\mathrm{TES}^{+} \rightarrow \mathrm{DES}(\text { neutral })+\mathrm{Li}^{+}+\mathrm{CH}_{3} \mathrm{CH}_{2}
$$

The detaching ethyl radical is an unstable component, which could be easily oxidized by $\mathrm{O}_{2}$ and $\mathrm{O}_{2}{ }^{-}$. We will discuss the reactions of the ethyl radical in the later sections. Figure $1 \mathrm{~b}$ shows a schematic illustration of the in-situ formation process of the organic film. According to this scheme, $\mathrm{I}^{-}$anions are released by the organic iodide. During repeated cycling, the $\mathrm{I}^{-}$anions are oxidized to $\mathrm{I}_{3}^{-}$anions, which act as $\mathrm{RM}$ in electrolyte and decrease the charging overpotential. At the same time, the organic cations $\left(\mathrm{TES}^{+}\right)$diffuse towards the Li metal, where chemically reductive reaction occurs spontaneously between the $\mathrm{TES}^{+}$and the $\mathrm{Li}$ metal. These reactions in situ form a SEI-like layer associated with DES and $\mathrm{CH}_{3} \mathrm{CH}_{2} \cdot$ radical on the surface of the $\mathrm{Li}$ anode, which protects the $\mathrm{Li}$ anode in $\mathrm{Li}-\mathrm{O}_{2}$ battery. The organic film conducts Li-ion efficiently and meanwhile blocks electrons. 
Electrochemical performance of TESI-containing $\mathrm{Li}-\mathrm{O}_{2}$ cell. The Li- $\mathrm{O}_{2}$ cell used in this work was composed of a $\mathrm{Li}$ anode, a porous cathode consisting of single walled carbon nanotubessingle layer graphene (SWNTs-SLG), a 1.0 M LiTFSI/TEGDME electrolyte with $50 \mathrm{mM}$ LiI or TESI additives. Discharge and charge profiles for the $\mathrm{Li}-\mathrm{O}_{2}$ cell with $50 \mathrm{mM}$ TESI at a current density of $500 \mathrm{~mA} \mathrm{~g}^{-1}$ are presented in Fig. 2a. Data for the $\mathrm{Li}-\mathrm{O}_{2}$ cell with $50 \mathrm{mM}$ LiI are provided for comparison. The TESIcontaining cell shows a discharge plateau at about $2.7 \mathrm{~V}$, which is similar to that of the LiI-containing cell. Moreover, the charging overpotential of the TESI-containing cell is even slightly lower than that of the LiI-containing cell. These results indicate that $\mathrm{I}_{3}{ }^{-}$ and $\mathrm{I}_{2}$ in the TESI-containing $\mathrm{Li}-\mathrm{O}_{2}$ cell act as a redox couple efficiently, similar to LiI. Figure $2 \mathrm{~b}$ shows the discharge/charge curves of $\mathrm{Li}-\mathrm{O}_{2}$ batteries with $50 \mathrm{mM}$ TESI additive at a current density of 250,500 , and $1000 \mathrm{~mA} \mathrm{~g}^{-1}$ for the first cycle. The charging voltage platform at $1000 \mathrm{~mA} \mathrm{~g}^{-1}(0.61 \mathrm{~V})$ is just slightly higher than that at 250 and $500 \mathrm{~mA} \mathrm{~g}^{-1}(0.49 \mathrm{~V})$. A large change in current density with a small shift in the voltage platform demonstrates the outstanding oxygen evolution reaction performance and electrochemical stability of the TESI.

Figures $2 \mathrm{c}-\mathrm{f}$ show the XRD patterns from the cathode discharged to $1.8 \mathrm{mAh}$ capacity and then charged with $50 \mathrm{mM}$ TESI or LiI. For comparison, the same experiments were carried out with $100 \mathrm{mM}$ TES and LiI. With $50 \mathrm{mM}$ TESI or LiI, the cells mainly exhibited the formation and decomposition of $\mathrm{Li}_{2} \mathrm{O}_{2}$. When concentrated TESI or LiI $(100 \mathrm{mM})$ were used, weak $\mathrm{LiOH}$
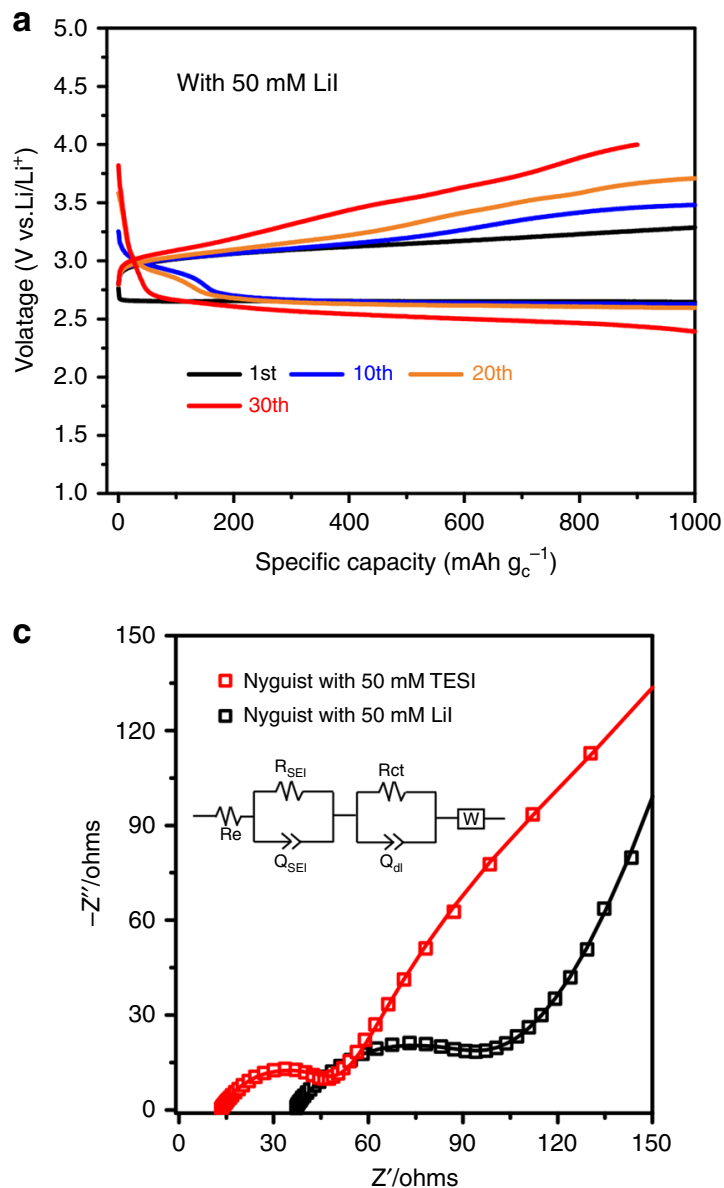

diffraction peaks appeared. The discharge products in the TESIcontaining $\mathrm{Li}-\mathrm{O}_{2}$ cell are consistent with those in the LiIcontaining cell.

The cycling performance of the TESI-containing and LiIcontaining $\mathrm{Li}-\mathrm{O}_{2}$ cells is shown in Fig. 3a, b. The discharge capacities of the electrodes are limited to $1000 \mathrm{mAh} \mathrm{g}^{-1}$. In Fig. 3b, the theoretical specific capacity delivered by the $\mathrm{I}^{-} / \mathrm{I}_{3}{ }^{-}$

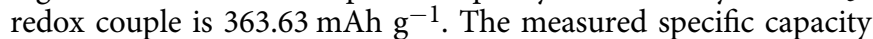
of the $\mathrm{I}^{-} / \mathrm{I}_{3}{ }^{-}$redox couple is $340.1 \mathrm{mAh} \mathrm{g}^{-1}$ in the $50 \mathrm{mM}$ TESIcontaining $\mathrm{Li}-\mathrm{O}_{2}$ cell. The efficiency of releasing $\mathrm{I}^{-}$by TESI is 93.52\%. Compared with the LiI-containing $\mathrm{Li}-\mathrm{O}_{2}$ cell (Fig. 3a), there are two beneficial results achieved from the TESI-containing cell (Fig. 3b). One is the improved cycling performance, which is superior to that of the LiI-containing one. The cell with $50 \mathrm{mM}$ TESI exhibits excellent cycle stability over 60 cycles of discharging/charging with relatively small overpotential. The other benefit is the increased discharge potential at the later part of discharging. The discharge median voltage of the first cycle is above $2.7 \mathrm{~V}$. Even after 60 cycles the voltage is still higher than $2.61 \mathrm{~V}$. In contrast, the cell with LiI can only work stably for 30 cycles, and the discharge median voltage was at the 30th cycle just $2.42 \mathrm{~V}$ (Fig. 3a). These provide an electrochemical evidence for our design, suggesting that the in-situ formation of organic compound-containing film effectively protects the Li metal anode from the attack of the soluble $\mathrm{I}_{3}{ }^{-}$, reducing the extra consumption of the $\mathrm{I}_{3}{ }^{-}$ions during charging and improving electrochemical performance.
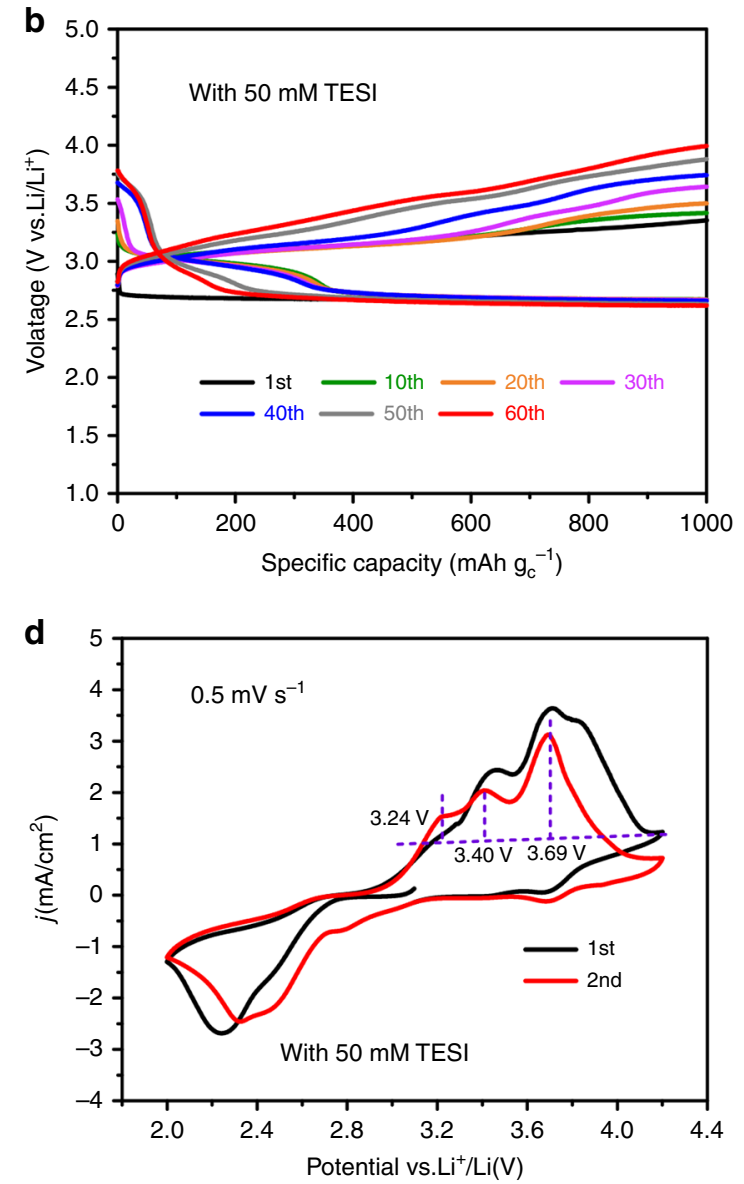

Fig. 3 Electrochemical performance of the Li- $\mathrm{O}_{2}$ cells with TESI or Lil at a limited specific capacity of $1000 \mathrm{mAh} \mathrm{g}^{-1}$. a With $50 \mathrm{mM} \mathrm{Lil} \mathrm{additive} \mathrm{for} 30$ cycles, current density: $500 \mathrm{~mA} \mathrm{~g}^{-1}$. b With $50 \mathrm{mM}$ TESI additive for 60 cycles, current density: $500 \mathrm{~mA} \mathrm{~g}^{-1}$. c EIS of the Li-O $\mathrm{O}_{2}$ cell after 30 cycles with $50 \mathrm{mM}$ TESI or $50 \mathrm{mM}$ Lil and EIS analysis using an equivalent circuit model (shown in the inset). d Cyclic voltammograms (CV) of the TESI-containing Li- $\mathrm{O}_{2}$ Cell 
The analysis of electrochemical impedance spectra (EIS) (Fig. 3c and Supplementary Fig. 2) indicates that the TESIcontaining $\mathrm{Li}-\mathrm{O}_{2}$ cell exhibits considerably smaller interfacial resistance than the LiI-containing cell. In order to avoid the influence of the cathode products, the $\mathrm{Li}-\mathrm{O}_{2}$ cells after 30 cycles with $50 \mathrm{mM}$ TESI or $50 \mathrm{mM}$ LiI were both reassembled with pristine air cathodes. Supplementary Table 1 shows the EIS of the $\mathrm{Li}-\mathrm{O}_{2}$ cells reassembled after 30 cycles. The TESI-containing $\mathrm{Li}-\mathrm{O}_{2}$ cell consistently exhibits smaller interfacial resistance than the LiI-containing cell. These results demonstrate that TESIcontaining cell can achieve an efficient Li-ion transfer.

The cyclic voltammograms (CVs) of the TESI-containing $\mathrm{Li}-\mathrm{O}_{2}$ cell (Fig. 3d) show reversible features at 3.24, 3.40, and $3.69 \mathrm{~V}$, which correspond to the reactions $\mathrm{LiO}_{2} \rightarrow \mathrm{O}_{2}+\mathrm{e}^{-}+\mathrm{Li}^{+}$, $\mathrm{Li}_{2} \mathrm{O}_{2} \rightarrow \mathrm{O}_{2}+2 \mathrm{e}^{-}+2 \mathrm{Li}^{+}$, and $3 \mathrm{I}^{-} \rightarrow \mathrm{I}_{3}^{-}+2 \mathrm{e}^{-}$, respectively. These assignments are consistent with the $\mathrm{Li}_{2} \mathrm{O}_{2}$ and $\mathrm{LiO}_{2}$ oxidation before $3.5 \mathrm{~V}$ and the following $\mathrm{I}_{3}^{-} / \mathrm{I}^{-}$redox process between 3.5 and $4.0 \mathrm{~V}$, suggesting that the organic iodide possesses similar $\mathrm{Li}_{2} \mathrm{O}_{2}$ oxidation behavior to the inorganic LiI. Note that both the first discharge curves show a flat plateau at around $2.7 \mathrm{~V}$, whereas the subsequent discharge profiles show shoulders at higher potentials. This is due to the reductive reaction of $\mathrm{I}_{3}^{-}+2 \mathrm{e}^{-} \rightarrow 3 \mathrm{I}^{-}$at air cathode because it is common that part of $\mathrm{I}_{3}-$ remains after the first charging process ${ }^{24}$. The $\mathrm{I}_{3}{ }^{-} / \mathrm{I}^{-}$discharge potential is consistent with that in $\mathrm{Li}-\mathrm{I}_{2}$ cells ${ }^{26}$. The typical redox behavior of iodine has been well characterized by previous studies of halogen electrochemistry ${ }^{26,27}$. Therefore, this work will focus on revealing the functions of $\mathrm{TES}^{+}$cation.

Synergic analysis of the functions of TES $^{+}$cation. To gain further insight into the functions of $\mathrm{TES}^{+}$cation on air cathode and $\mathrm{Li}$ anode, the air cathode and $\mathrm{Li}$ anode after cycling were investigated by scanning electron microscope (SEM), Fourier transform infrared (FTIR), gas chromatography-mass spectrometry analysis (GC-MS) and X-ray photoelectron spectroscopy (XPS). The SEM images of the fresh air cathodes are presented in Supplementary Fig. 4. The SEM images of the air cathodes after cycling in $\mathrm{Li}-\mathrm{O}_{2}$ cells with TESI or LiI additives are shown in Supplementary Fig. 5. XPS spectra on the surface of the same air cathodes are shown in Supplementary Fig. 6. From the analyses of the air cathodes (Supplementary Notes 1 and 2), there is no significant function of $\mathrm{TES}^{+}$cation on air cathode. Therefore, this work will focus on revealing the function of $\mathrm{TES}^{+}$cation on $\mathrm{Li}$ anode.

The SEM image of the $\mathrm{Li}$ anode in the TESI-containing $\mathrm{Li}-\mathrm{O}_{2}$ cell after 60 cycles shows a thin fluffy layer at the $\mathrm{Li}$ anode surface (Fig. 4a). This can be observed more clearly at a higher magnification (Fig. 4b). Figure $4 \mathrm{c}$ shows the SEM image of the $\mathrm{Li}$ anode surface in the LiI-containing $\mathrm{Li}-\mathrm{O}_{2}$ cell after 30 cycles. In contrast, gully domains due to the lithium dissolution and ridge domains owing to the lithium deposition were clearly observed. The difference of the surface morphology suggests that the surface layer formed in the TESI-containing $\mathrm{Li}-\mathrm{O}_{2}$ cell facilitates the Li-ion transfer, hence suppressing the accumulation of the $\mathrm{Li}$ on the surface. In addition, the SEM images of Li metal anodes in the TESI-containing and LiI-containing $\mathrm{Li}-\mathrm{O}_{2}$ cells after the first cycle are provided in the SI (Supplementary Fig. 7). The observed results are consistent with that in Figs. 4 a-c.

FTIR measurements were then performed. The results are shown in Fig. 4d. The peaks at 1457 and $1390 \mathrm{~cm}^{-1}$ correspond to the $\mathrm{O}-\mathrm{C}=\mathrm{O}$ vibrations of $\mathrm{Li}_{2} \mathrm{CO}_{3}$, and the peak at $1620 \mathrm{~cm}^{-1}$ is attributed to $\mathrm{CH}_{3} \mathrm{CO}_{2} \mathrm{Li}^{28}$. The characteristic peaks at $2920 \mathrm{~cm}^{-1}$ and $2866 \mathrm{~cm}^{-1}$ correspond to the $-\mathrm{C}_{2} \mathrm{H}_{5}$ group ${ }^{29}$, and the peak at $1105 \mathrm{~cm}^{-1}$ arises from the $\mathrm{C}-\mathrm{C}$ stretching ${ }^{30}$. We also observe a peak at $455 \mathrm{~cm}^{-1}$, which corresponds to the $\mathrm{C}-\mathrm{S}$ bond ${ }^{31}$. The
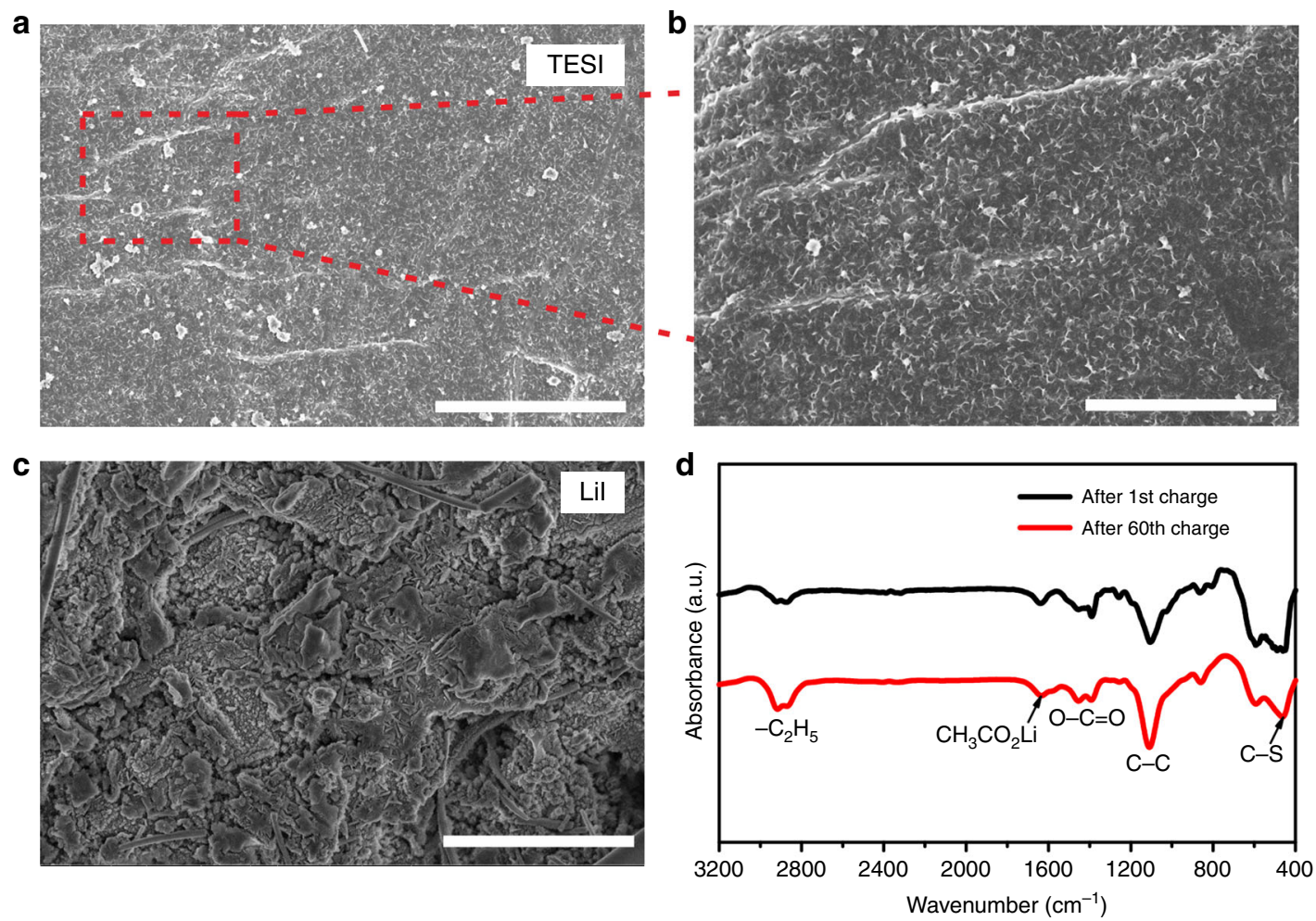

Fig. 4 Surface analysis of the Li anodes after cycling in $\mathrm{Li}_{-} \mathrm{O}_{2}$ cells. a, b SEM images of the Li anode after the 60 cycles with $50 \mathrm{mM}$ TESI. Scale bars are $4 \mu \mathrm{m}$ (a) and $2 \mu \mathrm{m}$ (b). c SEM image of the Li anode after 30 cycles with $50 \mathrm{mM}$ Lil. Scale bar is $4 \mu \mathrm{m}$. d FTIR spectra on the surface of the Li anode after 1 cycle and 60 cycles with $50 \mathrm{mM}$ TESI additive 

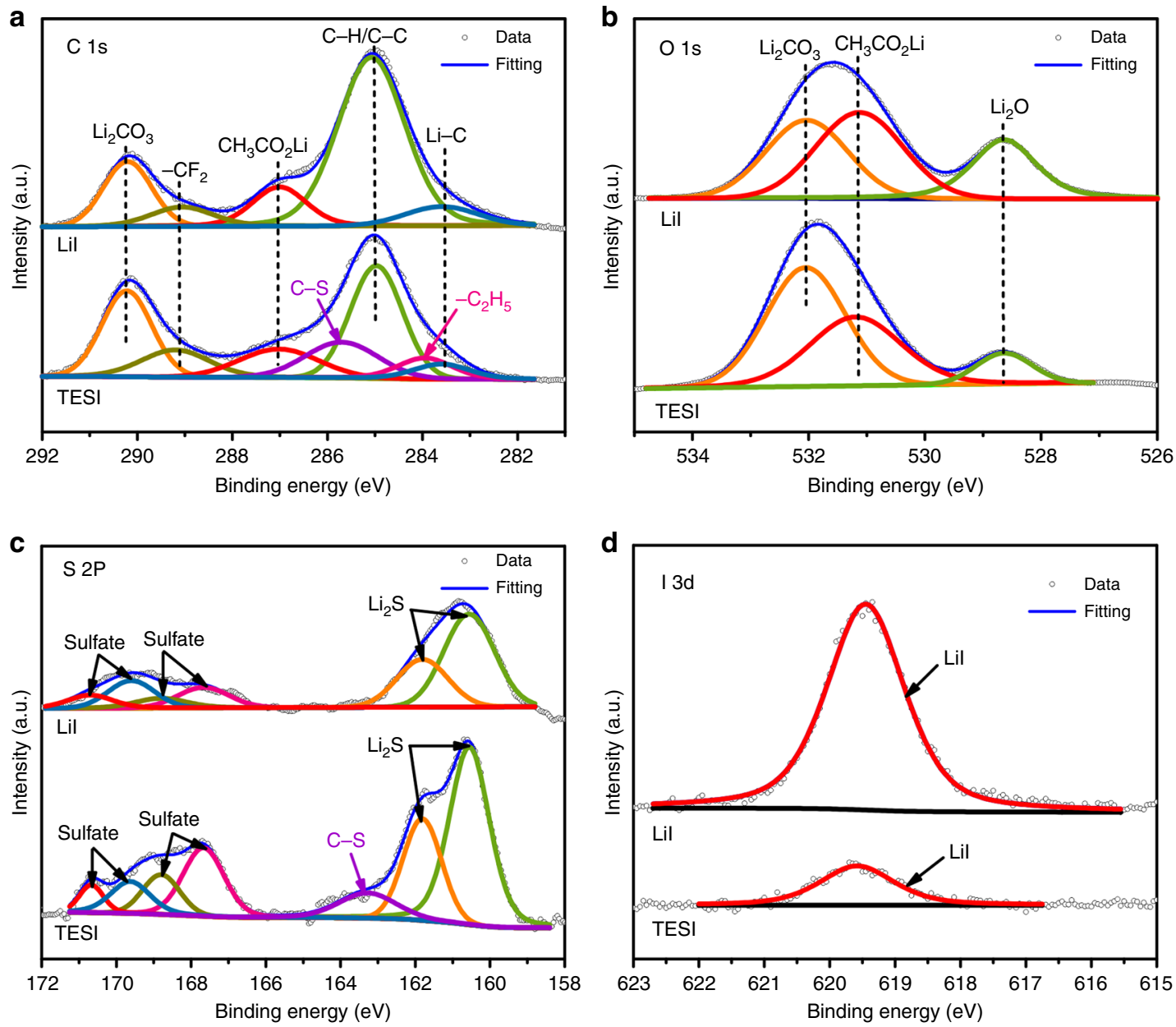

Fig. 5 XPS spectra on the surface of Li anodes. Two samples from the $\mathrm{Li}_{-} \mathrm{O}_{2}$ cells with $50 \mathrm{mM}$ TESI after 60 cycles and $50 \mathrm{mM}$ Lil additives after 30 cycles were measured. a C 1s spectra. b O 1s spectra. c S $2 p$ spectra. d I 3d spectra

presence of the $\mathrm{C}_{2} \mathrm{H}_{5}$ ethyl group and $\mathrm{C}-\mathrm{S}$ bonds provides direct evidence that the surface layer is mainly derived from the TES + and DES, because the $\mathrm{C}_{2} \mathrm{H}_{5}$ and $\mathrm{C}-\mathrm{S}$ bonds are their typical features.

XPS measurements were carried out to further confirm the element components of the surface layer in the TESI-containing $\mathrm{Li}-\mathrm{O}_{2}$ batteries, as shown in Fig. 5. The XPS spectra of Li metal anodes in the TESI-containing $\mathrm{Li}-\mathrm{O}_{2}$ cell after the first cycle are provided in the SI (Supplementary Fig. 8). Figure 5a shows the XPS profiles of $\mathrm{C} 1 \mathrm{~s}$ acquired from the $\mathrm{Li}$ anodes in the $\mathrm{Li}-\mathrm{O}_{2}$ cell with $50 \mathrm{mM}$ TESI or $50 \mathrm{mM}$ LiI additives after repeated cycling, respectively. The peaks at $283.5 \mathrm{eV}$ and $284.9 \mathrm{eV}$ are assigned to $\mathrm{Li}-\mathrm{C}$ bond and C-H/C-C group of TEGDME electrolyte ${ }^{32}$, and the three peaks at 287.2, 289.0, and $290.2 \mathrm{eV}$ can be ascribed to $\mathrm{CH}_{3} \mathrm{CO}_{2} \mathrm{Li},-\mathrm{CF}_{2}$ and $\mathrm{Li}_{2} \mathrm{CO}_{3}$, respectively ${ }^{33,34}$. Importantly, C-S and $\mathrm{C}_{2} \mathrm{H}_{5}$ bonds located at 285.7 and $283.9 \mathrm{eV}$ are only observed for the $\mathrm{Li}$ metal in the TESI-containing $\mathrm{Li}-\mathrm{O}_{2}$ cell, further indicating that the surface layer is mainly derived from the TES $^{+}$ and $\mathrm{DES}^{35}$. In the spectra of $\mathrm{O} 1 \mathrm{~s}$ (Fig. 5b), the peaks at 528.6, 531.3 , and $532.0 \mathrm{eV}$ are attributed to $\mathrm{Li}_{2} \mathrm{O}, \mathrm{CH}_{3} \mathrm{CO}_{2} \mathrm{Li}$, and $\mathrm{Li}_{2} \mathrm{CO}_{3}$, respectively ${ }^{36}$. In the $\mathrm{S} 2 \mathrm{p}$ spectrum of the $\mathrm{Li}$ metals (Fig. 5c), two close peaks located at 161.8 and $160.6 \mathrm{eV}$ correspond, respectively, to $S 2 p_{1 / 2}$ and $S 2 p_{3 / 2}$ of chemical bonding for $\mathrm{Li}_{2} \mathrm{~S}^{37}$, and the peak at $163.4 \mathrm{eV}$ corresponds to $\mathrm{C}-\mathrm{S}$ bond ${ }^{38}$. These results are consistent with the $\mathrm{C} 1 \mathrm{~s}$ XPS results. The peaks at $167.5,168.7,169.6$, and $170.8 \mathrm{eV}$ can be attributed to sulfate $^{38}$. It is worth noting that in the spectra of I $3 d$ (Fig. $5 d$ ), the signal of LiI species in the $\mathrm{Li}$ anodes from the TESIcontaining $\mathrm{Li}-\mathrm{O}_{2}$ cell is much weaker than that in the LiIcontaining $\mathrm{Li}-\mathrm{O}_{2}$ cell, indicating that the TESI-derived surface layer can efficiently protect $\mathrm{Li}$ anode from electronic reduction with soluble triiodide.

The GC-MS was employed to analyze the chemical species on the surface of the Li anode with $50 \mathrm{mM}$ TESI additive. In the extracted chromatogram $(\mathrm{m} / z$ 90) (Fig. 6a), the peak at $2.97 \mathrm{~min}$ is assigned to DES. The corresponding mass spectrum of the fragment peaks of DES is shown in Fig. $6 \mathrm{~b}(\mathrm{~m} / z 90)$. It is worth noting that $\mathrm{m} / z 92$ is the isotope of DES. This result provides direct evidence that DES does exist on the surface of the Li anode after 60 cycles with the TESI additive.

After characterizing the components of the SEI layer on the $\mathrm{Li}$ anode with $50 \mathrm{mM}$ TESI, we further analyze the forming process of the SEI layer by Raman spectroscopy. The results are shown in Supplementary Fig. 9, where the peak at $600 \mathrm{~cm}^{-1}$ is the characteristic peak of TESI. The Raman spectra show that the characteristic peak of TESI after the first cycle is weaker than that in pristine electrolyte with $50 \mathrm{mM}$ TESI. After five cycles, the characteristic signal of TESI completely disappears, indicating that the SEI layer is formed in the first five cycles and then stabilized.

The analyses above demonstrate that the SEI layer mainly consists of organic components, DES and $\mathrm{CH}_{3} \mathrm{CO}_{2} \mathrm{Li}$, and inorganic components, $\mathrm{Li}_{2} \mathrm{CO}_{3}, \mathrm{Li}_{2} \mathrm{O}$, and $\mathrm{Li}_{2} \mathrm{~S}$. The organic component DES only appears on the $\mathrm{Li}$ anode from the 

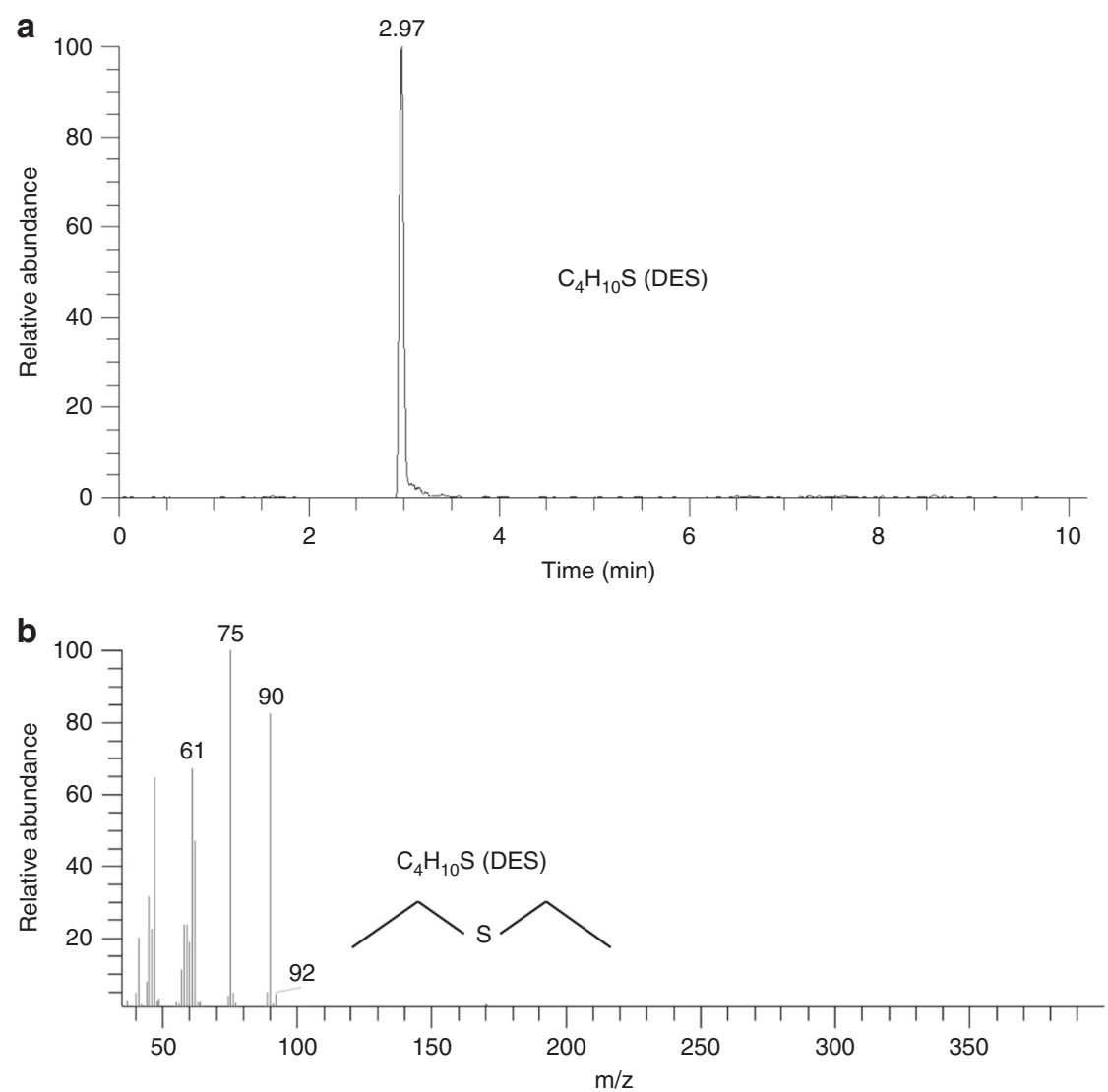

Fig. 6 GC-MS measurement. The extracted chromatogram $(m / z 90)$ and DES mass spectra $(D E S=m / z 90)$ were taken from the Li anode of the Li-O $\mathrm{O}_{2}$ cell with $50 \mathrm{mM}$ TESI after 60 cycles. a Extracted chromatogram. b DES mass spectra (DES $=m / z$ 90)

TESI-containing $\mathrm{Li}-\mathrm{O}_{2}$ cell, which is the key component in the SEI layer. Organic components combined with inorganic lithium salts results in a SEI-like layer which exhibits better uniformity, ionic conductivity and flexibility than inorganic SEI layers.

\section{Discussion}

To evaluate the long-term stability of Li plating/stripping behavior in a battery, $\mathrm{Li} \mid \mathrm{Cu}$ cells in the presence of $\mathrm{O}_{2}$ with $\mathrm{LiI}$ and TESI additives were assembled. For Li | Cu cells, high Coulombic efficiency (CE) is a good indicator of the formation of a SEI-like layer. In the presence of $\mathrm{O}_{2}$, the initial $\mathrm{CE}$ of the cells with $\mathrm{LiI}$ or TESI additives is $86.63 \%$ and $93.36 \%$ at $0.5 \mathrm{~mA} \mathrm{~cm}^{-2}$, respectively. After 70 cycles, the CE of LiI is evidently lower than $80 \%$, while a remarkably high $\mathrm{CE}$ of $98 \%$ is achieved in the TESIcontaining $\mathrm{Li} \mid \mathrm{Cu}$ cell after 100 cycles, as shown in Fig. 7a, b. The corresponding EIS shown in Fig. 7c indicates that the TESIcontaining $\mathrm{Li} \mid \mathrm{Cu}$ cell facilities the Li-ion transfer.

In the TESI-containing $\mathrm{Li} \mid \mathrm{Cu}$ cells, morphologies of $\mathrm{Li}$ anode were recorded (Supplementary Fig. 10) after 100 cycles. A thin, uniform and flexible layer without any porous structure covers the deposited lithium and effectively transports Li-ions, such that Li metal deposition takes place underneath the SEI layer without forming dendrites. XPS analysis was used to further investigate the surface components of the anode in the TESI-containing $\mathrm{Li} \mid \mathrm{Cu}$ cell (Fig. $7 \mathrm{~d}-\mathrm{f}$ ). In the presence of $\mathrm{O}_{2}$, the SEI-like layer is mainly composed of organic components (Supplementary Fig. 11 and Supplementary Note 3) involving DES, $\mathrm{CH}_{3} \mathrm{CO}_{2} \mathrm{Li}$ and inorganic components (e.g., $\mathrm{Li}_{2} \mathrm{CO}_{3}, \mathrm{Li}_{2} \mathrm{O}$, and $\mathrm{Li}_{2} \mathrm{~S}$ ), which achieves high ionic conductivity and dendritefree $\mathrm{Li}$ deposition.
The protective behavior of the SEI-like layer has been revealed in the presence of $\mathrm{O}_{2}$. We further assembled gastight $\mathrm{Li} \mid \mathrm{Cu}$ cells to study whether similar behavior exists in the absence of $\mathrm{O}_{2}$. In this case, the TESI-containing $\mathrm{Li} \mid \mathrm{Cu}$ cell shows $84.8 \% \mathrm{CE}$ in the first cycle and the CE increases gradually to over $95 \%$ after 80 cycles (Fig. 8a). However, for the LiI-containing cell, the CE value is $81.9 \%$ in the first cycle, starts to decrease after 50 cycles, and significantly decreases to only $57.7 \%$ after 80 cycles (Fig. 8 b). The reasons for the fading of $\mathrm{CE}$ after 50 cycles are as follows: (1) the sharply increased impedance, (2) an uneven lithium surface, and (3) optically visible dead lithium on the Cu substrate (Supplementary Figs. 12 and 13). The corresponding EIS suggests that the TESI-containing $\mathrm{Li} \mid \mathrm{Cu}$ cell facilities the Li-ion transport (Supplementary Fig. 14 and Supplementary Table 2). The surface morphology of the Li anodes after 80 cycles was also recorded. From Fig. 8c, d, it is observed that uneven growth of the electrodeposited lithium occurs in the LiI-containing $\mathrm{Li}-\mathrm{Cu}$ cell, which produces Li dendrites that are exposed on the surface of $\mathrm{Li}$ anode. In sharp contrast, there is no clear Li dendrite formation observed on the surface of $\mathrm{Li}$ anode in the TESI-containing $\mathrm{Li}$ | $\mathrm{Cu}$ cell, which suggests that the deposition of lithium occurs mainly under a surface layer on the Li anode. Large-area SEM images of the Li anodes from TESI-containing and LiI-containing $\mathrm{Li} \mid \mathrm{Cu}$ cells are shown in Supplementary Fig. 15, where a flatter surface can be observed on the TESI-containing cell than that on the LiI-containing cell.

The same surfaces as in the SEM experiment were analyzed by XPS. Fig. 8e, f show the C 1 s and S 2p XPS spectra. The Li anode from the TESI-containing cell generates the XPS peak that can be assigned to C-S bond, while this peak is absent in the Li anode from the LiI-containing cell. The component of 

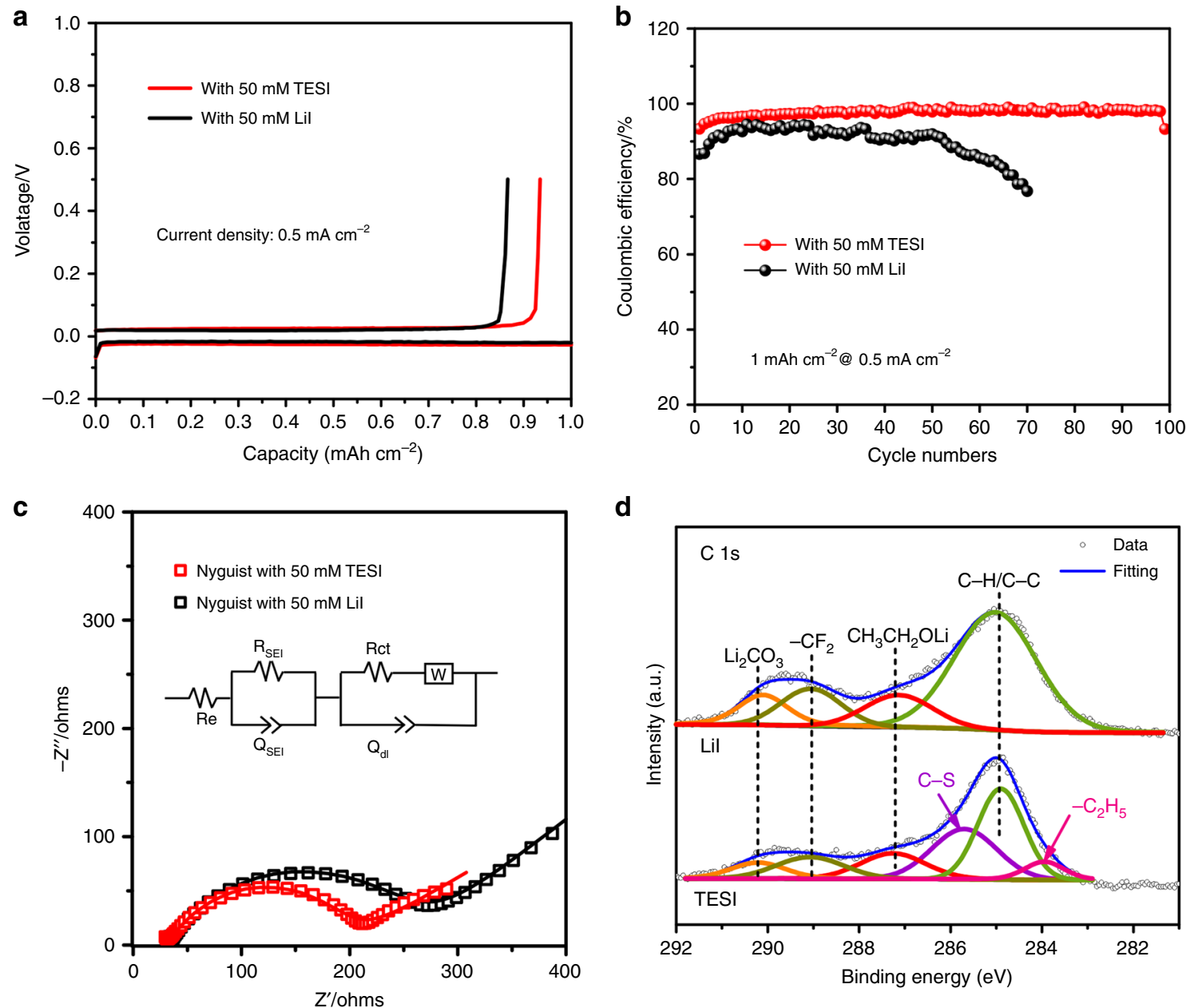

d

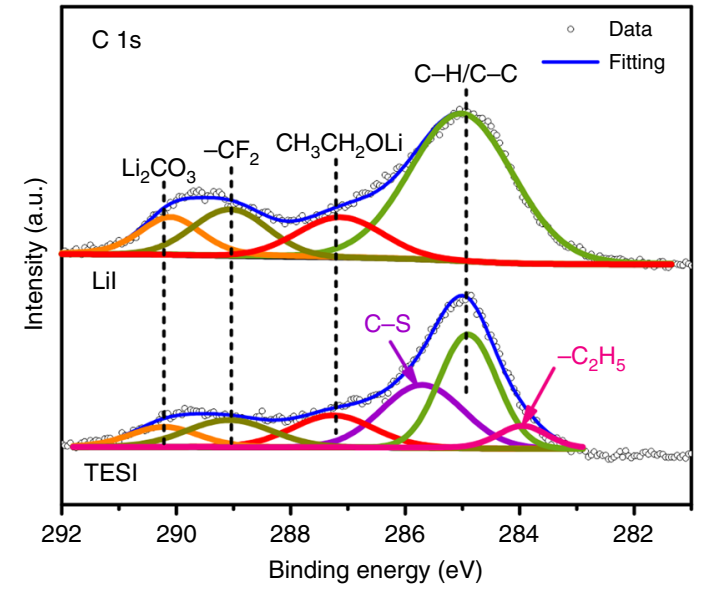

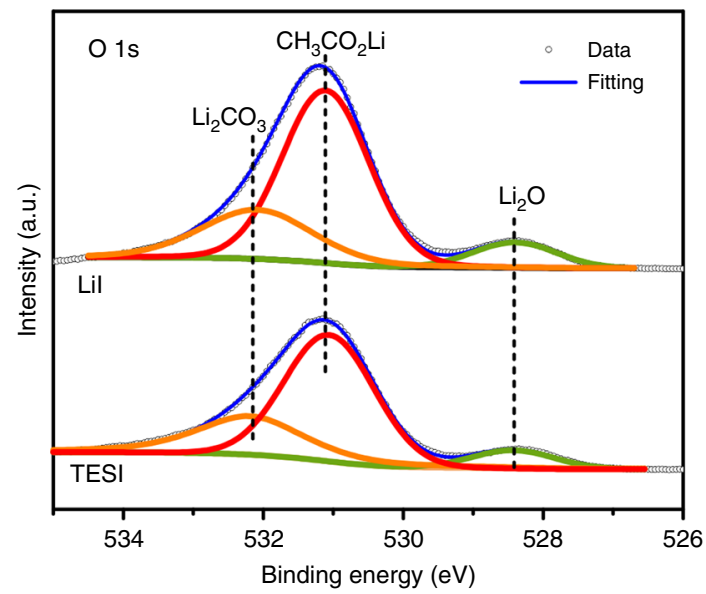

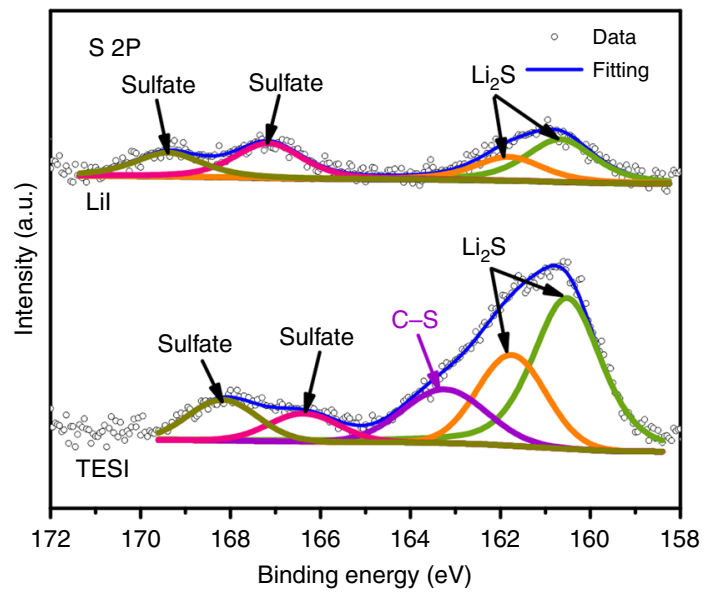

Fig. 7 Electrochemical performance and analysis of the Li anodes from $\mathrm{Li} \mid \mathrm{Cu}$ cells in the presence of $\mathrm{O}_{2}$ with a limited specific capacity of $1 \mathrm{mAh} \mathrm{cm}^{-2}$. a Galvanostatic discharge/charge profile at $0.5 \mathrm{~mA} \mathrm{~cm}-2$. b Subsequent cycles, current density: $0.5 \mathrm{~mA} \mathrm{~cm}^{-2}$. c EIS of the Li|Cu cells after 100 cycles with $50 \mathrm{mM}$ TESI or $50 \mathrm{mM}$ Lil, and EIS analysis using an equivalent circuit model (shown in the inset). d-f XPS spectra of the Li anodes after 100 cycles with $50 \mathrm{mM}$ TESI and $50 \mathrm{mM}$ Lil additive

$\mathrm{CH}_{3} \mathrm{CO}_{2} \mathrm{Li}$ is absent in the TESI-containing cell (Supplementary Fig. 16 and Supplementary Note 4). These results suggest that the $\mathrm{Li}$ anode indeed reacts with the $\mathrm{TES}^{+}$, however, the oxidation process of the detached $\mathrm{CH}_{3} \mathrm{CH}_{2}$. radical cannot proceed in the absence of $\mathrm{O}_{2}$.

Combining all the data above, the SEI-like layer formation in the $\mathrm{Li}-\mathrm{O}_{2}$ cell containing the organic iodide TESI is proposed as follows: (1) a reductive ethyl detaching process occurs at $\mathrm{Li}$ anode, releasing $\mathrm{CH}_{3} \mathrm{CH}_{2}$. radical and neutral DES molecule. The reductive process includes the chemical reaction between $\mathrm{Li}$ atoms and TES ${ }^{+}$; (2) The $\mathrm{CH}_{3} \mathrm{CH}_{2}$. radical react rapidly with $\mathrm{O}_{2}$ and $\mathrm{O}_{2}{ }^{-}$to produce $\mathrm{CH}_{3} \mathrm{CO}_{2} \mathrm{Li}$, and the DES molecules absorb on the surface of $\mathrm{Li}$ anode. The resulting surface layer not only consists of the inorganic components, such as $\mathrm{Li}_{2} \mathrm{CO}_{3}, \mathrm{Li}_{2} \mathrm{O}$ and 

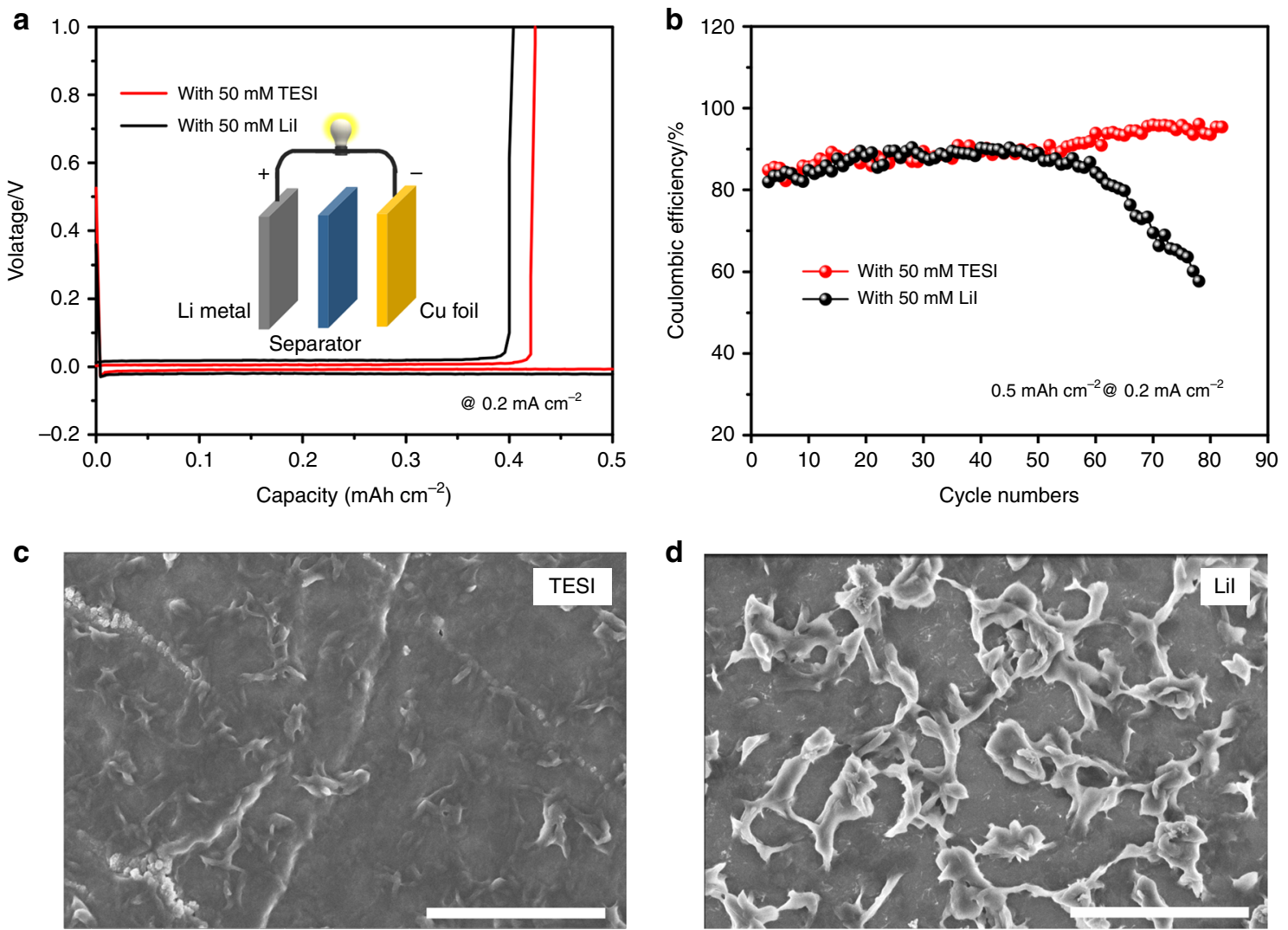

d

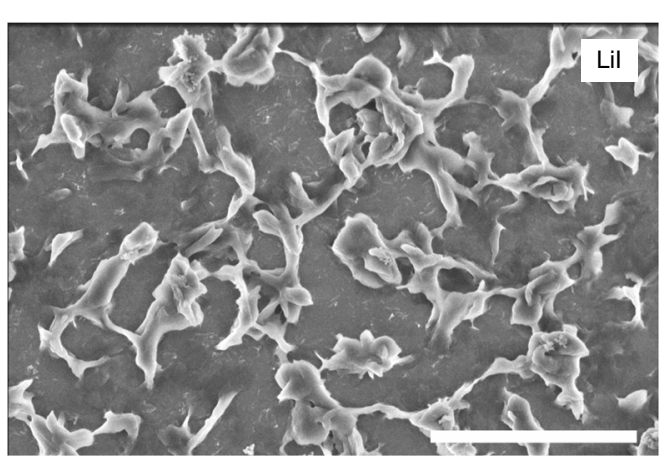

e

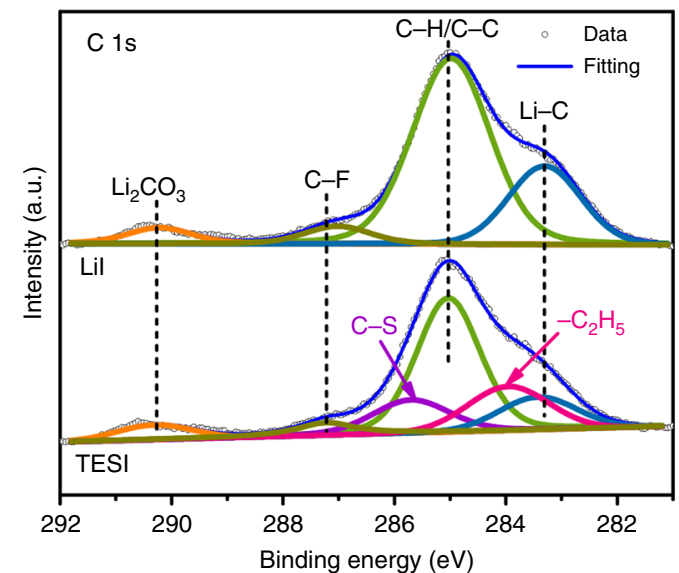

f

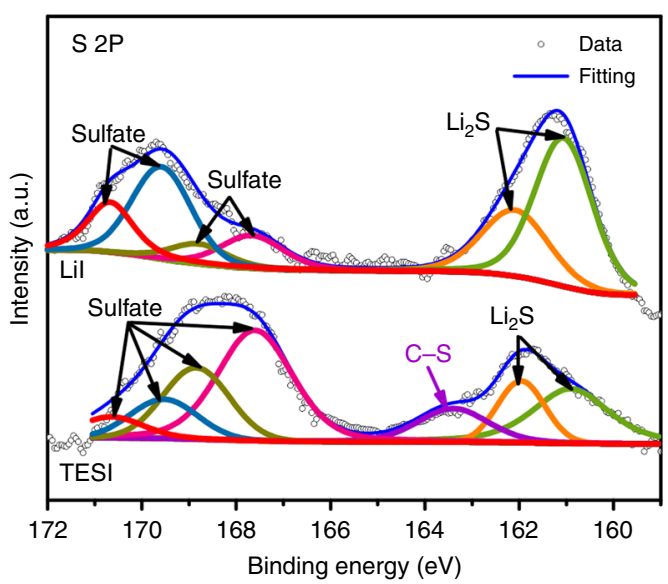

Fig. 8 Electrochemical performance and analysis of the Li anodes of Li | Cu cells with a limited specific capacity of $0.5 \mathrm{mAh} \mathrm{cm}^{-2}$. a Galvanostatic discharge/charge profile at $0.2 \mathrm{~mA} \mathrm{~cm}^{-2}$. b Subsequent cycles, current density: $0.2 \mathrm{~mA} \mathrm{~cm}^{-2}$. c SEM image of the Li anode after $80 \mathrm{cycles}$ with $50 \mathrm{mM}$ TESI additive. Scale bar is $2 \mu \mathrm{m}$. d SEM image of the Li anode after the 80 cycles with $50 \mathrm{mM}$ Lil additive. Scale bar is $2 \mu \mathrm{m}$. e C $1 \mathrm{~s}$ XPS spectra of the Li anodes after 80 cycles. $\mathbf{S} 2 \mathrm{p}$ XPS spectra of the Li anodes after 80 cycles

$\mathrm{Li}_{2} \mathrm{~S}$, but also the organic components, such as DES and $\mathrm{CH}_{3} \mathrm{CO}_{2} \mathrm{Li}$. The organic components, especially DES, play an important role on transferring Li-ion favorably, similar to the SEI from the viewpoint of structure and function. The related oxidation reactions of $\mathrm{CH}_{3} \mathrm{CH}_{2}$. radical are:

$$
\begin{gathered}
2 \mathrm{CH}_{3} \mathrm{CH}_{2} \cdot+1.5 \mathrm{O}_{2} \rightarrow 2 \mathrm{CH}_{3} \mathrm{CHO}+\mathrm{H}_{2} \mathrm{O} \\
\mathrm{CH}_{3} \mathrm{CHO}+\mathrm{O}_{2}^{-} \rightarrow \mathrm{CH}_{3} \mathrm{CO} \cdot+\mathrm{HO}_{2}^{-} \\
2 \mathrm{CH}_{3} \mathrm{CO} \cdot+\mathrm{O}_{2}+2 \mathrm{Li} \rightarrow 2 \mathrm{CH}_{3} \mathrm{CO}_{2} \mathrm{Li}
\end{gathered}
$$

For the neutral DES molecules, the GC-MS and XPS results have demonstrated that they still remain on the surface of $\mathrm{Li}$ anode in the TESI-containing $\mathrm{Li}-\mathrm{O}_{2}$ cell after 60 cycles. However, partial DES molecules could be transformed into $\mathrm{Li}_{2} \mathrm{~S}$ under the reduction of $\mathrm{Li}$ metal during repeated cycling. Generally, $\mathrm{Li}_{2} \mathrm{~S}$ is mainly derived from the decomposition of the Li salt, as displayed in the LiI-containing cells. The related reduction reactions of DES with Li metal may be:

$$
\begin{gathered}
\mathrm{CH}_{3} \mathrm{CH}_{2} \mathrm{SCH}_{2} \mathrm{CH}_{3}(\mathrm{DES})+\mathrm{Li} \rightarrow \mathrm{CH}_{3} \mathrm{CH}_{2} \cdot+\mathrm{LiSCH}_{2} \mathrm{CH}_{3} \\
\mathrm{LiSCH}_{2} \mathrm{CH}_{3}+\mathrm{Li} \rightarrow \mathrm{CH}_{3} \mathrm{CH}_{2}+\mathrm{Li}_{2} \mathrm{~S}
\end{gathered}
$$

It is relevant here to recall the issues of SEI component 
a

Cycle lifes of various $\mathrm{Li}-\mathrm{O}_{2}$ batteries

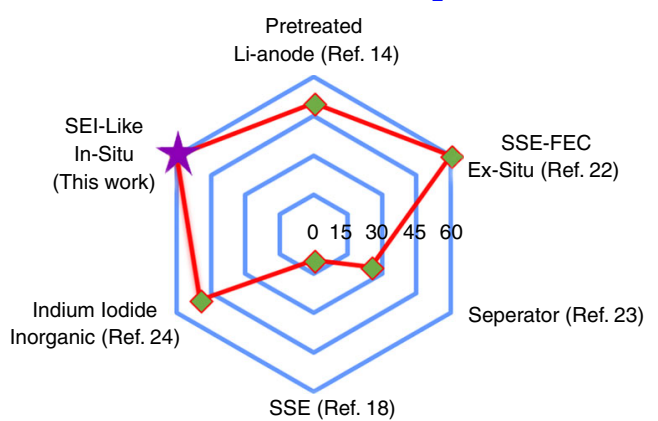

b

Coulombic efficiencies of various Li-metal batteries

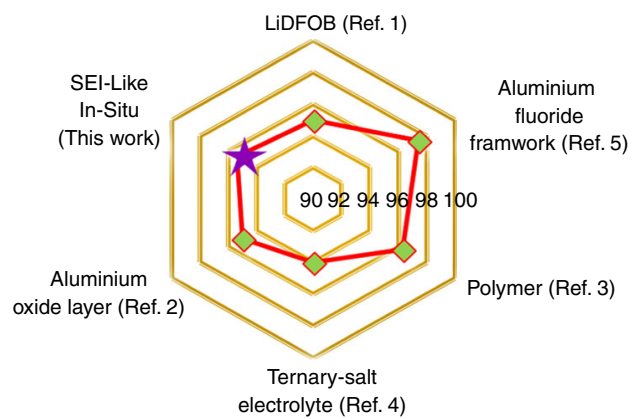

Fig. 9 Summary of the performance of recently reported interfacial engineering methods improving the Li metal anode. a Cycling performance of various $\mathrm{Li}_{-} \mathrm{O}_{2}$ batteries. $\mathbf{b}$ Coulombic efficiency of various Li-metal batteries

modification mentioned in the introduction section. Our results address these issues from the following aspects: (1) reductive ethyl detaching is a fundamental process to properly introduce organic components in an organic-inorganic hybrid SEI layer on $\mathrm{Li}$ anode; and (2) the oxidation process in the presence of $\mathrm{O}_{2}$ and its intermediates $\mathrm{O}_{2}{ }^{-}$is essential to produce a SEI-like layer on the $\mathrm{Li}$ metal. In terms of battery performance, the TESI-containing $\mathrm{Li}-\mathrm{O}_{2}$ cell exhibits improved cycling performance over the cells using other approaches to suppressing the shuttle effect of RMs, such as pre-treated lithium anode ${ }^{14}$, solid-state electrolytes ${ }^{18,22}$, modified separators ${ }^{23}$, and inorganic $\mathrm{InI}_{3}{ }^{24}$, as compared in Fig. 9a. Moreover, taking a broad view of interfacial engineering for next-generation lithium metal batteries, the CE of the lithium metal in this work is on par with those previously reported values (Fig. 9b) ${ }^{1-5}$. Giving the variety of organic iodide compounds, both ionic and covalent types, more research could be conducted to further improve lithium metal anode performance.

In summary, triethylsulfonium iodide is found to be chemically reduced on metallic $\mathrm{Li}$ anode, in situ forming a SEI-like layer between electrolyte and $\mathrm{Li}$ anode through reductive ethyl detaching and subsequent oxidation during the first few cycles of $\mathrm{Li}-\mathrm{O}_{2}$ batteries. Different from the previously reported inorganic solid-state electrolytes or $\mathrm{Li}$-In alloying protective layer, the SEI-like layer reported here is an organic and inorganic composite interface, which possesses high stability against the attack of soluble triiodide. More importantly, Li-ions can pass freely through the SEI-like layer such that deposition can take place underneath the layer without forming dendrites. Our results represent a new approach for RM developments based on bifunctional organic iodide. In particular, the reductive ethyl detaching can be used as a useful descriptor for screening candidate compounds for more bifunctional RMs which can produce SEI-like layer in the oxidation environment of $\mathrm{Li}-\mathrm{O}_{2}$ batteries.

\section{Methods}

SWNT-SLG-IL gel. SWNTs (10 mg, Hipco Super pure) and SLG (1.36 mg, ACS Materials) were dispersed in $0.6 \mathrm{ml}$ imidazolium ion-based ionic liquid (IL) of 1 ethyl-3-methylimidazolium $\left(\left[\mathrm{C}_{2} \mathrm{C}_{1} \mathrm{im}\right]\right)$ bis(tri-fluoromethylsulfonyl) $\left(\left[\mathrm{NTf}_{2}\right]\right)$ by ultrasonic dispersion ${ }^{39}$. The suspension was ground together with $2 \mathrm{mg}$ PTFE in an agate mortar for $10 \mathrm{~min}$. With grinding, the SWNTs bundles and SLG sheets were bound by PTFE particles together into a spherical paste. After grinding continuously for about $30 \mathrm{~min}$, the paste began to spread and become sticky. The subsequent grinding up to $60 \mathrm{~min}$ turned the paste to a viscous gel, accompanied by a visible volume expansion ${ }^{39}$.

SWNT-SLG-IL gel-derived air cathodes. The as-prepared SWNT-SLG-IL gel was casted onto round-shape carbon paper with a diameter of $12 \mathrm{~mm}$. The carbon paper with SWNT-SLG-IL gel was immersed first in NMP solvent for 30 min for 2 times, and then dried at $60^{\circ} \mathrm{C}$ for $24 \mathrm{~h}$. The obtained solid film was immersed in a solvent of ethanol-acetonitrile mixture for $12 \mathrm{~h}$ and then dried at $110^{\circ} \mathrm{C}$ for $12 \mathrm{~h}$. By the 2-step extraction method, IL was removed completely from the SWNTSLG-IL gel. The finally obtained solid film was used as SWNT-SLG-IL gel-derived air cathode. The loading area of the SWNT-SLG gel-derived air cathodes was a square of $0.25 \mathrm{~cm}^{-2}$ on a carbon paper current collector. The loading weight of the SWNT-SLG was $\sim 0.11 \mathrm{mg}$.

Li anode. A $0.2-\mathrm{mm}$-thick $\mathrm{Li}$ foil was cut into a disc of $12.0 \mathrm{~mm}$ in diameter, and then pressed onto a stainless steel spacer in $\mathrm{Li}-\mathrm{O}_{2}$ cells.

Cu foil. A 0.25 -mm-thick $\mathrm{Cu}$ foil was cut into a disc of $10.0 \mathrm{~mm}$ in diameter.

Electrolyte and separator. A TEGDME-based electrolyte consists of Li salt of $1 \mathrm{M}$ bis (trifluoromethane sulfonyl) imide (LiTFSI). $50 \mathrm{mM}$ Triethylsulfonium Iodide (TESI) or lithium iodide (LiI) was added as RMs. The amount of the electrolyte was $60 \mu \mathrm{L}$, immersed in a Waterman GF/C glass fiber separator.

Assembling $\mathbf{L i}-\mathrm{O}_{\mathbf{2}}$ cell. Two-electrode cells configuration using CR2032 coin-type cells with holes for $\mathrm{O}_{2}$ access was employed and assembled in an Ar-filled glove box with $\mathrm{O}_{2}$ and $\mathrm{H}_{2} \mathrm{O}$ content below $0.5 \mathrm{ppm}$. The $\mathrm{Li}$ foil and air cathode were the working electrodes. After assembling, the cells were operated in $1.0 \mathrm{mbar}$ of pure $\mathrm{O}_{2}$.

Assembling $\mathbf{L i} \mid \mathbf{C u}$ half-cell (in the presence of $\mathbf{O}_{2}$ ). Two-electrode cells configuration using CR2032 coin-type cells with holes for $\mathrm{O}_{2}$ access was employed and assembled. The $\mathrm{Li}$ foil and $\mathrm{Cu}$ foil were the working electrodes. After assembling, the cells were operated in 1.0 mbar of pure $\mathrm{O}_{2}$.

Assembling Li | Cu half-cell. Two-electrode cells configuration using standard CR2025 coin-type cells was employed and assembled. The Li foil and Cu foil were the working electrodes. After assembling, the cells were operated in air.

Density functional theory calculation. Our calculations were based on the density functional theory (DFT) implemented in the VASP program ${ }^{40}$ using a planewave basis set. The kinetic cutoff energy for the planewaves was set to $30 \mathrm{Ry}$. The ionic cores were represented by the projector-augmented wave (PAW) potentials ${ }^{41}$. We used the Perdew-Burke-Ernzerhof (PBE) exchange-correlation functional ${ }^{42}$. Structural optimizations were carried out until the force on each atom was smaller than $0.5 \mathrm{mRy} /$ Bohr.

Electrochemical measurement. The current density was constant with a lower voltage limit of $2.0 \mathrm{~V}$ (vs. $\mathrm{Li} / \mathrm{Li}^{+}$) and upper limit of $4.0 \mathrm{~V}$ (vs. $\mathrm{Li} / \mathrm{Li}^{+}$) at $25^{\circ} \mathrm{C}$ after a $3 \mathrm{~h}$ rest period. All the specific capacities were calculated by normalizing with the weight of the SWNTs-SLG. The electrochemical tests at $25^{\circ} \mathrm{C}$ charge/discharge were performed using a Land battery tester (LAND CT2001) and Autolab instruments. The EIS measurement was performed in a frequency range from $10^{6}$ to $10^{-1} \mathrm{~Hz}$ under amplitude of $10 \mathrm{mV}$ using Autolab 84640 electrochemical workstation (Metrohm Autolab B.V., The Netherlands). The equivalent circuit used for fitting the EIS spectra is from a previous publication ${ }^{43}$.

Sample preparation. All samples for analyses were prepared in the argon-filled glove box, washed by 1,2-dimethoxyethane (anhydrous, Sigma) for $0.5 \mathrm{~h}$ and then dried for $2 \mathrm{~h}$. A special transfer system was employed to transfer the samples from the glove box to the analyses system without being exposed to air. 
XRD analysis. X-ray powder diffraction (Rigaku) was used to analyze the crystalline structure of the air cathode after cycling.

SEM analyses. The Li anodes and cathodes after cycling were analyzed by the field emission scanning electron microscope (FESEM JSM-4800F) for micrograph observation.

FTIR analysis. The Li anodes after cycling were analyzed by Fourier transform infrared (FTIR, JASCO FT/IR-6200). The samples were ground together with $\mathrm{KBr}$ and pressed into pellets.

Raman analysis. Raman spectra were recorded with a Raman microspectrometer (Invia Renishaw, UK) using the $532 \mathrm{~nm}$ line of a semiconductor laser at room temperature.

XPS analysis. The Li anodes after cycling were analyzed by the X-ray photoelectron spectroscopy (XPS, Thermo Fisher Scientific ESCALAB 250).

GC-MS analysis. The analysis was performed on a Trace 1300 gas chromatograph coupled to a TSQ 8000 Evo triple quadrupole mass spectrometer and a TriPlus 300 autosampler (Thermo Fisher, Austin, TX, USA). The Li anode of the $\mathrm{Li}-\mathrm{O}_{2}$ cell with $50 \mathrm{mM}$ TESI after 60 cycles was prepared in the argon-filled glove box. The Li anode was put into a $20 \mathrm{ml}$ glass sample container. The container was transferred from the glove box to the GC-MS analysis system and heated at $90^{\circ} \mathrm{C}$ for $20 \mathrm{~min}$ to vaporize DES. $1000 \mu \mathrm{l}$ of headspace was immediately sampled using a gas syringe and injected in the ion-trap GC-MS, equipped with capillary column (TG-5, $30 \mathrm{~m} \times 0.25 \mathrm{~mm} \times 0.25 \mu \mathrm{m}$ ) using helium as gas carrier. The temperature program for the GC run was: $25^{\circ} \mathrm{C}$ initial column temperature, $10^{\circ} \mathrm{C} \mathrm{min}-1$ to $120^{\circ} \mathrm{C}$, held for 5 minutes. High purity helium gas was used as the carrier gas and the pressure was kept constant at $75 \mathrm{kPa}$.

\section{Data availability}

The data that support the findings of this study are available from the corresponding author upon request.

Received: 19 August 2018 Accepted: 18 July 2019

Published online: 07 August 2019

\section{References}

1. Jurng, S., Brown, Z. L., Kim, J. \& Lucht, B. L. Effect of electrolyte on the nanostructureof the solid electrolyte interphase (SEI) and performance of lithium metal anodes. Energy Environ. Sci. 11, 2600-2608 (2018).

2. Kozen, A. C. et al. Next-generation lithium metal anode engineering via atomic layer deposition. ACS Nano. 9, 5884-5892 (2015).

3. Wu, H., Cao, Y., Su, H. \& Wang, C. Tough gel electrolyte using double polymer network design for the safe, stable cycling of lithium metal anode. Angew. Chem. Int. Ed. 57, 1361-1365 (2018).

4. Zhao, C. Z. et al. $\mathrm{Li}_{2} \mathrm{~S}_{5}$-based ternary-salt electrolyte for robust lithium metal anode. Energy Storage Mater. 3, 77-84 (2016).

5. Wang, H., Lin, D., Liu, Y., Li, Y. \& Cui, Y. Ultrahigh-current density anodes with interconnected Li metal reservoir through overlithiation of mesoporous $\mathrm{AlF}_{3}$ framework. Sci. Adv. 3, el701301 (2017).

6. $\mathrm{Wu}, \mathrm{B}$. et al. The role of the solid electrolyte interphase layer in preventing $\mathrm{Li}$ dendrite growth in solid-state batteries. Energy Environ. Sci. 11, 1803-1810 (2018).

7. Bruce, P. G., Freunberger, S. A., Hardwick, L. J. \& Tarascon, J. M. Li-O 2 and Li-S batteries with high energy storage. Nat. Mater. 11, 19-29 (2012).

8. Shao, Y. Y. et al. Electrocatalysts for nonaqueous lithium-air batteries: status, challenges and perspective. Acs. Catal. 2, 844-857 (2012).

9. Girishkumar, G., McCloskey, B., Luntz, A. C., Swanson, S. \& Wilcke, W. Lithium-air battery: promise and challenges. J. Phys. Chem. Lett. 1, 2193-2203 (2010).

10. Bergner, B. J., Schurmann, A., Peppler, K., Garsuch, A. \& Janek, J. TEMPO: a mobile catalyst for rechargeable $\mathrm{Li}_{-} \mathrm{O}_{2}$ batteries. J. Am. Chem. Soc. 136, 15054-15064 (2014).

11. Lim, H. D. et al. Rational design of redox mediators for advanced $\mathrm{Li}-\mathrm{O}_{2}$ batteries. Nat. Energy 1, 16066 (2016).

12. Chen, Y., Freunberger, S. A., Peng, Z., Fontaine, O. \& Bruce, P. G. Charging a $\mathrm{Li}-\mathrm{O}_{2}$ battery using a redox mediator. Nat. Chem. 5, 489 (2013).

13. Yu, M., Ren, X., Ma, L. \& Wu, Y. Integrating a redox-coupled dye-sensitized photoelectrode into a lithium-oxygen battery for photoassisted charging. Nat. Commun. 5, 5111 (2014).
14. Sun, D. et al. A solution-phase bifunctional catalyst for lithium-oxygen batteries. J. Am. Chem. Soc. 136, 8941-8946 (2014).

15. Kundu, D., Black, R., Adams, B. \& Nazar, L. F. A highly active low voltage redox mediator for enhanced rechargeability of lithium-oxygen. Batter. ACS Cent. Sci. 1, 510-515 (2015)

16. Yao, K. P. C. et al. Utilization of Cobalt Bis(terpyridine) metal complex as soluble redox mediator in $\mathrm{Li}-\mathrm{O}_{2}$ Batteries. J. Phys. Chem. C 120, 16290-16297 (2016).

17. Feng, N., Mu, X., Zhang, X., He, P. \& Zhou, H. Intensive study on the catalytical behavior of $\mathrm{N}$-methylphenothiazine as a soluble mediator to oxidize the $\mathrm{Li}_{2} \mathrm{O}_{2}$ cathode of the Li- $\mathrm{O}_{2}$ battery. Acs. Appl. Mater. Interfaces $\mathbf{9}$, 3733-3739 (2017)

18. Bergner, B. J. et al. How to improve capacity and cycling stability for next generation $\mathrm{Li}-\mathrm{O}_{2}$ batteries: approach with a solid electrolyte and elevated redox mediator concentrations. Acs. Appl. Mater. Interfaces 8, 7756-7765 (2016).

19. Guo, Z., Li, C., Liu, J., Wang, Y. \& Xia, Y. A long-life lithium-air battery in ambient air with a polymer electrolyte containing a redox mediator. Angew. Chem. Int. Ed. 129, 7613-7617 (2017).

20. Wang, Y. \& Xia, Y. Li-O ${ }_{2}$ batteries: an agent for change. Nat. Chem. 5, 445 (2013).

21. Lee, D. J., Lee, H., Kim, Y. J., Park, J. K. \& Kim, H. T. Sustainable redox mediation for lithium-oxygen batteries by a composite protective layer on the lithium-metal anode. Adv. Mater. 28, 857-863 (2016).

22. Kwak, W. J., Jung, H. G., Aurbach, D. \& Sun, Y. K. Optimized bicompartment two solution cells for effective and stable operation of $\mathrm{Li}-\mathrm{O}_{2}$. Batter. Adv. Energy Mater. 7, 1701232 (2017).

23. Lee, S. H., Park, J. B., Lim, H. S. \& Sun, Y. K. An advanced separator for $\mathrm{Li}-\mathrm{O}_{2}$ batteries: maximizing the effect of redox mediators. Adv. Energy Mater. 7, 1602417 (2017).

24. Zhang, T., Liao, K., He, P. \& Zhou, H. A self-defense redox mediator for efficient lithium $-\mathrm{O}_{2}$ batteries. Energy Environ. Sci. 9, 1024-1030 (2016).

25. Schulz, N. et al. XPS-surface analysis of SEI layers on Li-Ion cathodes: part I. Investigation of initial surface chemistry. J. Electrochem. Soc. 165, A819-A832 (2018).

26. Zhao, Y., Wang, L. \& Byon, H. R. High-performance rechargeable lithiumiodine batteries using triiodide/iodide redox couples in an aqueous cathode. Nat. Commun. 4, 1896 (2013).

27. Liang, Z. \& Lu, Y. C. Critical role of redox mediator in suppressing charging instabilities of lithium-oxygen batteries. J. Am. Chem. Soc. 138, 7574-7583 (2016).

28. Freunberger, S. A. et al. The lithium-oxygen battery with ether-based electrolytes. Angew. Chem. Int. Ed. 50, 8609-8613 (2011).

29. Webb, L. J., Rivillon, S., Michalak, D. J., Chabal, Y. J. \& Lewis, N. S Transmission infrared spectroscopy of methyl- and ethyl-terminated silicon (111) surfaces. J. Phys. Chem. B 110, 7349-7356 (2006).

30. Wolpert, M. \& Hellwig, P. Infrared spectra and molar absorption coefficients of the 20 alpha amino acids in aqueous solutions in the spectral range from 1800 to $500 \mathrm{~cm}^{-1}$. Acta A. Mol. Biom. Spectrosc. 64, 987-1001 (2006).

31. Li, X., Lau, S. P., Tang, L., Ji, R. \& Yang, P. Sulphur doping: a facile approach to tune the electronic structure and optical properties of graphene quantum dots. Nanoscale 6, 5323-5328 (2014).

32. Gu, Y. et al. Designable ultra-smooth ultra-thin solid-electrolyte interphases of three alkali metal anodes. Nat. Commun. 9, 1339 (2018).

33. Zhang, W. et al. Promoting $\mathrm{Li}_{2} \mathrm{O}_{2}$ oxidation via solvent-assisted redox shuttle process for low overpotential $\mathrm{Li}_{-} \mathrm{O}_{2}$ battery. Nano Energy 30, 43-51 (2016).

34. Perry, C. C., Wagner, A. J. \& Howard Fairbrother, D. Electron stimulated C-F bond breaking kinetics in fluorine-containing organic thin films. Chem. Phys. 280, 111-118 (2002).

35. Zhang, C. et al. Reduction of graphene oxide by hydrogen sulfide: a promising strategy for pollutant control and as an electrode for Li-S batteries. $A d v$. Energy Mater. 4, 1301565 (2014).

36. Yao, K. P. C. et al. Thermal stability of $\mathrm{Li}_{2} \mathrm{O}_{2}$ and $\mathrm{Li}_{2} \mathrm{O}$ for Li-air batteries: In situ XRD and XPS studies. J. Electrochem. Soc. 160, A824-A831 (2013).

37. Benoist, L. et al. XPS analysis of oxido-reduction mechanisms during lithium intercalation in amorphous molybdenum oxysulfide thin films. Solid. State Ion. 76, 81-89 (1995).

38. Yao, J. et al. Hollow carbon spheres with $\mathrm{TiO}_{2}$ encapsulated sulfur and polysulfides for long-cycle lithium-sulfur batteries. Chem. Engine J 330, 644-650 (2017).

39. Zhang, T., Matsuda, H. \& Zhou, H. Gel-derived cation-pi stacking films of carbon nanotube-graphene complexes as oxygen cathodes. Chemsuschem 7, 2845-2852 (2014).

40. Kresse, G. \& Furthmuller, J. Efficiency of ab-initio total energy calculations for metals and semiconductors using a plane-wave basis set. Comput. Mater. Sci. 6, 15-50 (1996). 
41. Kresse, G. \& Joubert, D. From ultrasoft pseudopotentials to the projector augmented-wave method. Phys. Rev. B 59, 1758-1775 (1999).

42. Perdew, J. P., Burke, K. \& Ernzerhof, M. Generalized gradient approximation made simple. Phys. Rev. Lett. 77, 3865-3868 (1996).

43. Zhang, S. S., Xu, K. \& Jow, T. R. EIS study on the formation of solid electrolyte interface in Li-ion battery. Electrochim. Acta 51, 1636-1640 (2006).

\section{Acknowledgements}

This work was supported financially by the "Hundred Talents" program of the Chinese Academy of Sciences (2015), "The Recruitment Program of Global Experts" in Shanghai (2016), as well as by the National Natural Science Foundation of China under Grant No. 21875278, 51672299 .

\section{Author contributions}

T.Z. conceived and designed the experiments. X.Z. performed the experiment. X.Z., T.Z., Y.S., Z.S. and C.Y. carried out the data analysis. T.Z., X.Z., and Y.S. wrote the paper.

\section{Additional information}

Supplementary Information accompanies this paper at https://doi.org/10.1038/s41467 019-11544-8.

Competing interests: The authors declare no competing interests.
Reprints and permission information is available online at http://npg.nature.com/ reprintsandpermissions/

Peer review information: Nature Communications thanks the anonymous reviewer(s) for their contribution to the peer review of this work.

Publisher's note: Springer Nature remains neutral with regard to jurisdictional claims in published maps and institutional affiliations.

\section{(c) (i)}

Open Access This article is licensed under a Creative Commons Attribution 4.0 International License, which permits use, sharing, adaptation, distribution and reproduction in any medium or format, as long as you give appropriate credit to the original author(s) and the source, provide a link to the Creative Commons license, and indicate if changes were made. The images or other third party material in this article are included in the article's Creative Commons license, unless indicated otherwise in a credit line to the material. If material is not included in the article's Creative Commons license and your intended use is not permitted by statutory regulation or exceeds the permitted use, you will need to obtain permission directly from the copyright holder. To view a copy of this license, visit http://creativecommons.org/licenses/by/4.0/.

(C) The Author(s) 2019 